\title{
Electrical Energy Demand Planning in District Mlati Sleman Yogyakarta Year $2014-2020$
}

\author{
Danang Ario $\mathrm{R}^{\mathrm{a}}$, Irma Lelawati ${ }^{\mathrm{a}}$, Bernando ${ }^{\mathrm{a}}$, Prihastomo Triaji ${ }^{\mathrm{a}}$ \\ ${ }^{a}$ Department of Engineering Physics, Faculty of Engineering, Gadjah Mada University, Jln Grafika No. 2, D.I Yogyakarta 55281, Indonesia
}

\begin{abstract}
Mlati subdistrict, Sleman is one area in Yogyakarta, which has potential for very rapid development. Residents of Mlati are immigrants who mostly are students who are studying in Yogykarta. It can give us potential in planning of electrical energy demand. In event of an energy crisis, it will hinder economic growth in industrial sector, commercial, business, public services which would certainly hamper improvement of social welfare. From data of population and economic growth, energy consumption profile, then using software LEAP (Long-range Energy Alternative Planning system) that can be predicted by a pattern on the allocation of necessary electrical energy. Aim of this paper is planning availability electricity demand using LEAP in District Mlati 2020.
\end{abstract}

Keywords: energy consumption; energy demand; LEAP.

\section{Introduction}

Indonesia is one of the developing countries that have high levels of electricity usage continues to grow. The availability of sufficient electrical energy and will spur the development of targeted development areas such as industrial, commercial, public service and even quality of life with more and more people who enjoy electricity. Then it does not directly or indirectly, the use of electricity growth will affect economic growth and the welfare of society in Indonesia.

Mlati subdistrict, Sleman is one area in Indonesia, which has the potential for very rapid development. Also in this Mlati many districts are immigrants who mostly are students who are studying in Yogykarta. It can give us the potential that could be a model Mlati District of us in the planning of the electrical energy demand.

The model can then be used as a reference to be able to provide recommendations - recommendations of what needs to be done to maintain the availability of local Muspida electrical energy and see how the development of the electricity demand in the period that we have set.

Electricity planning in Indonesia and elsewhere needs to be done to anticipate the energy crisis. In the event of an energy crisis, it will hinder economic growth in the industrial sector, commercial, business, public services and so on, which would certainly hamper the improvement of social welfare. From the data of population growth and economic growth, as well as energy consumption profile, then using software LEAP (Long- range Energy Alternative Planning system) that can be predicted by a pattern on the allocation of the necessary electrical energy.

The aim of this paper is planning electricity demand using LEAP in District Mlati 2020 to the availability of electrical energy in the future.

\footnotetext{
* Corresponding author. Tel.: +62 8572540 6752; fax: +62 2518323339.

E-mail address: irmalelawati600@gmail.com
} 


\section{Material and method}

By using software LEAP (Long-range Energy Alternative Planning system) can be obtained on demand forecasting and supply of electric energy throughout the year desired period. However, in this study, which is the scope of the study or the extent of the problem in this research are:

- The scope of the demand planning Mlati electricity needs in the district.

- Electric customers only covers the household and business sector because there is no industry in the District Mlati and comparative scope of public service sector and the social sector too little when compared to households or businesses.

- There is no natural resource sector are included in the calculation of LEAP.

- There is no sector emissions are included in the calculation of LEAP.

- There is no transformation sectors are included in the calculation of LEAP.

- Forecast demand for electrical energy that is used in the District Mlati with 2013 as the base projection and the year 2020 as the deadline for projection.

- The economic factor is only used in conjunction with energy elasticity and not included in the calculation framework of electrical energy demand forecast for LEAP does not have facilities for projection calculations in economics.

Mlati is a district in Sleman, Yogyakarta Special Region, Indonesia. Mlati sub-districts in the southern district of Sleman Capital. This district is inhabited by 23645 households. Mlati the District's total population is 72438 \pm soul. Most of the residents of the District Mlati are farmers. Of monographs, the District recorded 12196 people or residents of the District Mlati working in the agricultural sector. Camat the lead at the moment is Anggoro Mlati Sunaryono Aji, SH. Mlati administrative area of the District as follows:

- Sendangadi

- Sinduadi

- Sumberdadi

- Tirtoadi

- Tigoadi

Of the division of the village, the village Sinduadi an area with the largest electricity consumption levels. This happens because in the village there are many boarding Sinduadi where electrical energy usage levels are very high and will be much improved from the other side of energy use.

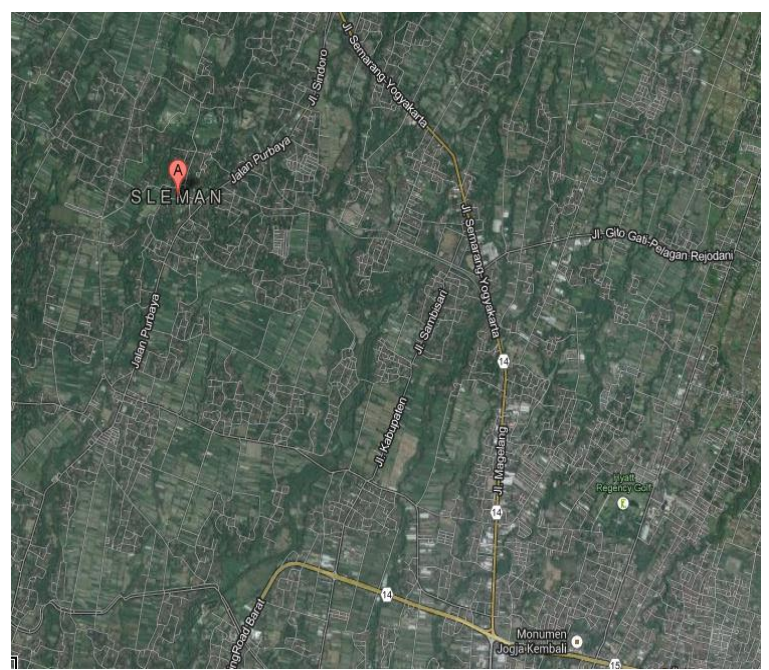

Fig. 1. Mlati area. 
Subdistrict Mlati a growth area of development is fairly rapid. Lots of green open land that was converted to a boarding house or housing and apartments. Mlati also one of the areas in Yogyakarta, which has many migrants, this happens because Mlati adjacent to one of the big campus in Yogyakarta, namely UGM. So, most of the entrants are students who settle temporarily.

LEAP is a very comprehensive energy plan. Many variables can be input variables such as income (GDP), population, until the projected demand. One solution that can be used is to conduct a study and simulation using software LEAP (Long- range Energy Alternative Planning system). The process of data entry on LEAP as follows:

\subsection{Determining basic parameters}

In 2013 became the basis for data entry because at the time of the first scenario LEAP calculations performed in 2014, and 2020 be the last year in the calculation of projected electricity demand.

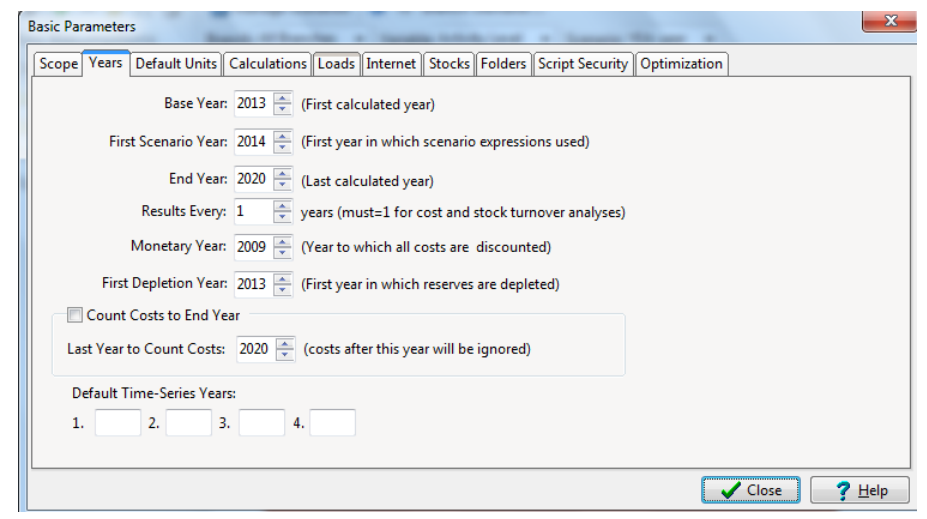

\subsection{Determining the manage scenarios}

Manage scenarios as value added in the base year.

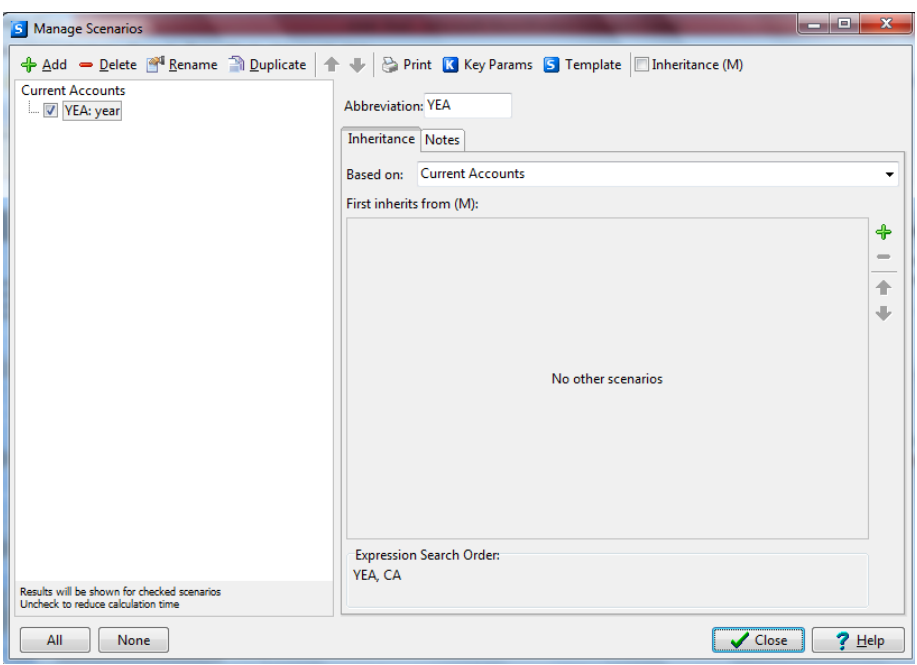




\subsection{Determine the input variables used in the key assumption}

To add a variable input, right click on the key assumption write select add column name in the add branch. At this time the LEAP Key Assumption is used as the business sector, the household sector, income, household size, income growth rate, and pop growth rate.

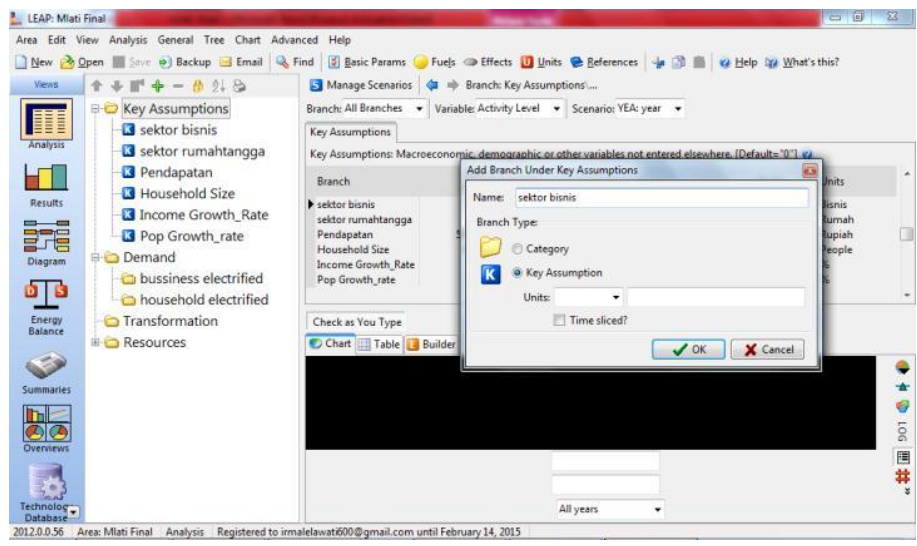

\subsection{Enter data, scale, and units acquired at key assumption}

The business sector is the number of businesses in the district Mlati some 200 businesses. Household sector is the number of homes located in the district Mlati house number 6500 . Income is income of the entire population Mlati of Rp540 million. Household size is the number of people Mlati number 65000 . Income growth is the growth rate of the economy in a number of districts Mlati $4.3 \%$. Pop growth rate of population growth in the district namely Mlati number of $1.31 \%$.

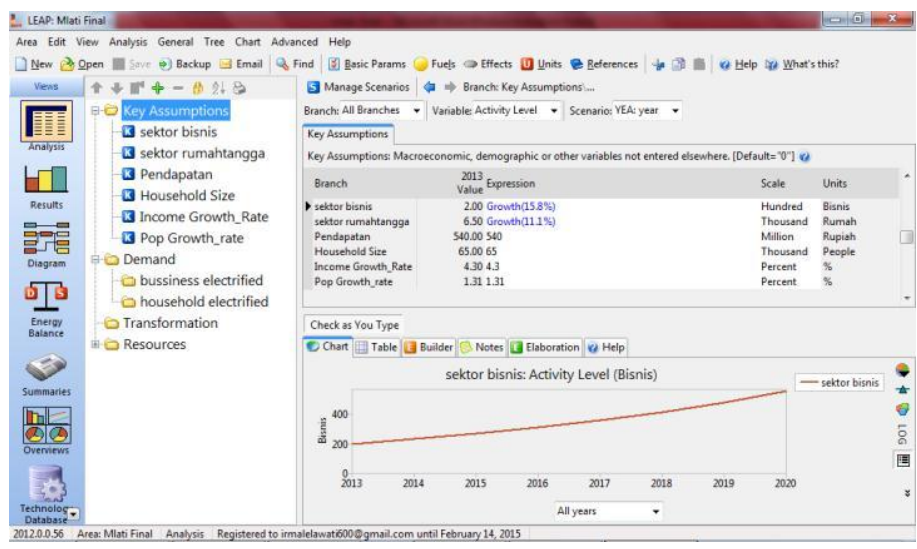

\subsection{Determine the input variables used in demand}

To add a variable input, right click select add on demand write a column name in the add branch. At this time it is used as a LEAP Demand is bussiness electrified and electrified household. 


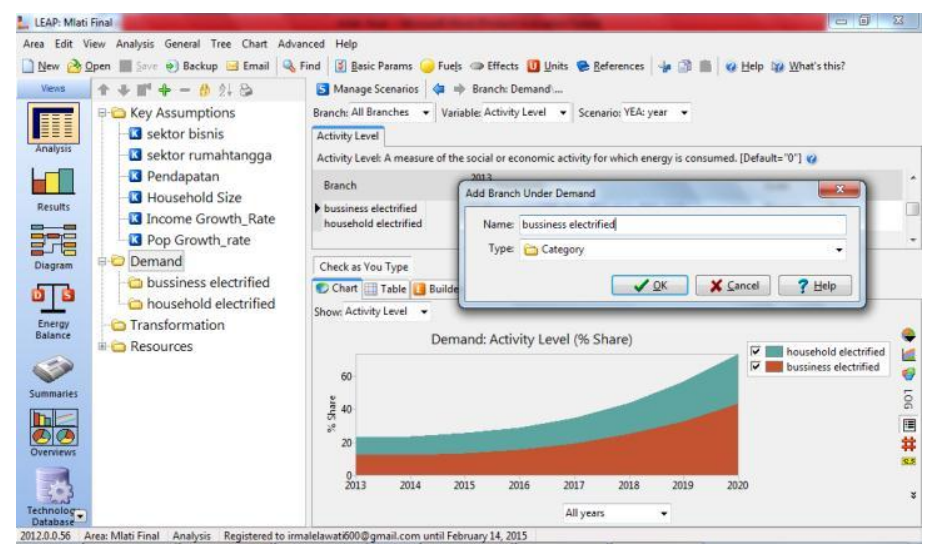

\subsection{Enter data, scale, and units acquired on demand}

Bussiness electrified namely electricity consumption in the business sector. Ie electrified household electricity consumption in the household sector. The data used in the form of a percentage of annual demand growth.

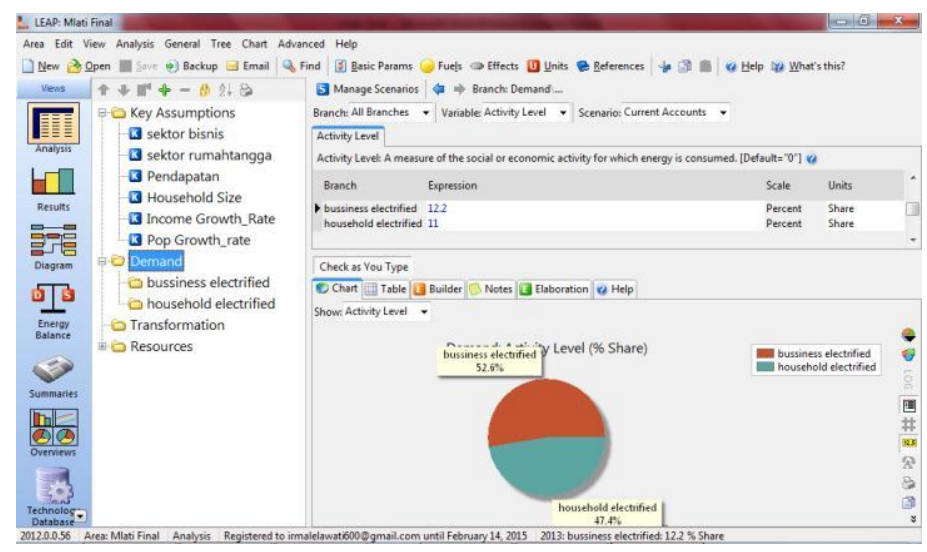

\subsection{Determining the expression of each data demand}

In the expression box right click select Interpolate select curves entering data and their 3-year percentage. 

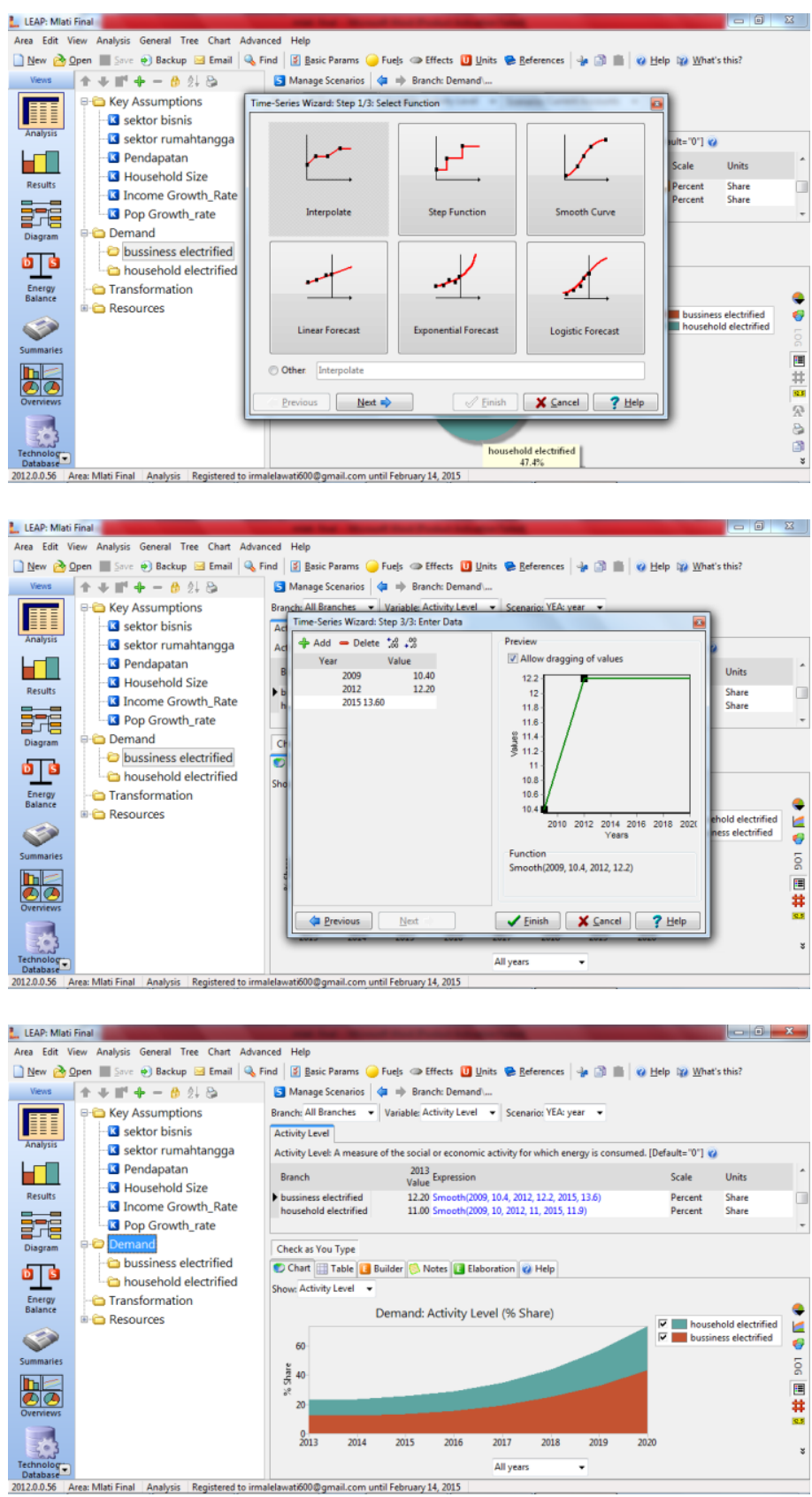

\subsection{Result}

Click to see the results of the graph result. The reading of the graph from right to left. 

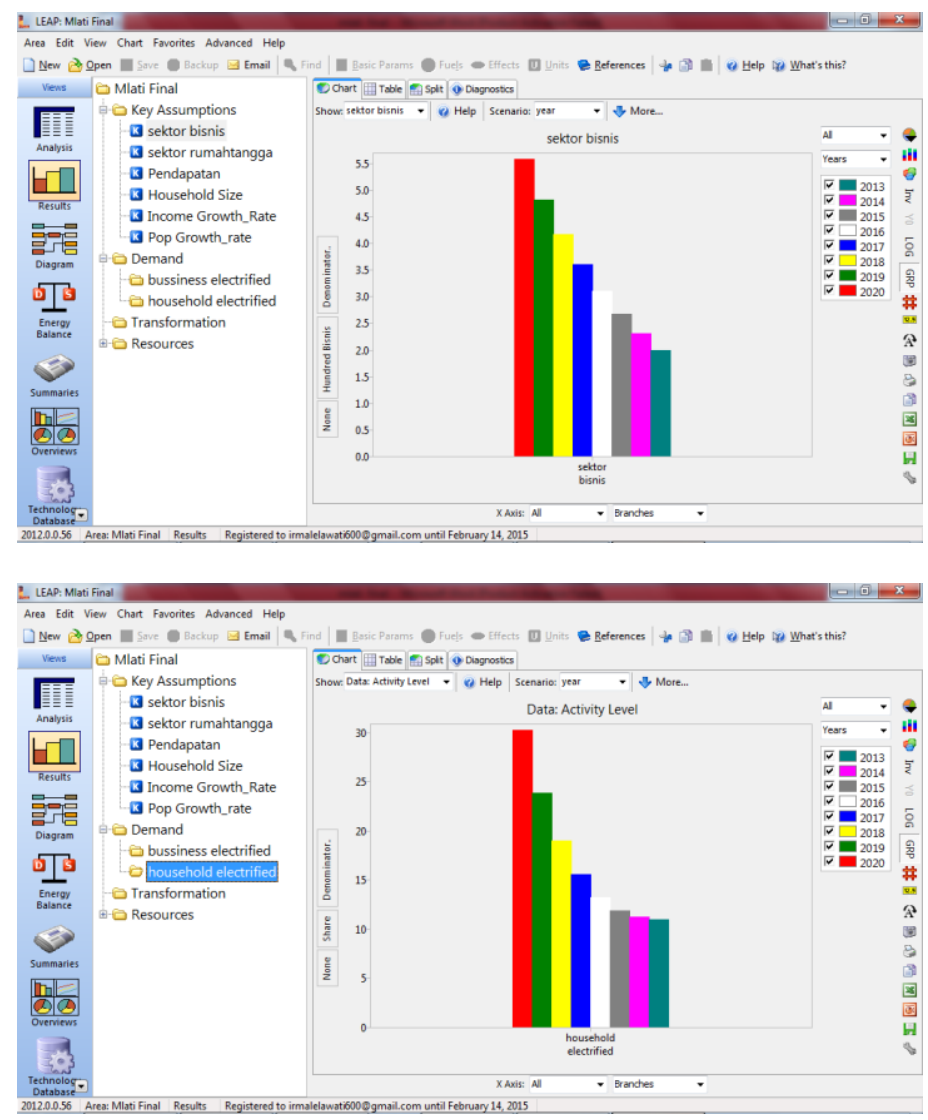

\section{Discussion}

The first discussion regarding the request module (Demand) in this report refer to the demand for electrical energy in the districts Mlati. Analysis is used in determining the rate of growth of demand using the data capacity of electric energy consumption Mlati districts in percentage (\%) of the years 2008 to 2013. The data used as the base year is the percentage (\%) of electrical energy consumption in 2012.

Table 1. Electrical energy consumption by sector in Sleman.

\begin{tabular}{lrrrrrr}
\hline Sektor & \multicolumn{6}{c}{ Konsumsi Listrik(GWh) } \\
\cline { 2 - 7 } Tarif & $\mathbf{2 0 0 8}$ & $\mathbf{2 0 0 9}$ & $\mathbf{2 0 1 0}$ & $\mathbf{2 0 1 1}$ & $\mathbf{2 0 1 2}$ & $\mathbf{2 0 1 3}$ \\
\hline Bisnis & 124,91 & 133,30 & 142,25 & 151,80 & 162,00 & 172,88 \\
Industri & 114,51 & 123,45 & 133,09 & 143,48 & 154,68 & 166,75 \\
Publik & 35,59 & 38,67 & 42,01 & 45,65 & 49,59 & 53,88 \\
Sosial & 31,27 & 36,33 & 42,21 & 49,04 & 56,97 & 66,19 \\
Rumah & 357,28 & 383,19 & 410,99 & 440,80 & 472,77 & 507,06 \\
Tangga & 314,94 & 770,55 & 830,76 & 896,01 & 966,76 \\
Total & 663,56 & 714,
\end{tabular}


Data were obtained on an electricity consumption data in Sleman district. Mapping using the results of calculations per subdistrict electricity consumption growth data using LEAP software sourced from sister thesis Suhono battery.

Table 2. Proportion of electrical energy consumption per household sector in the district of Sleman regency.

\begin{tabular}{lrrrr}
\hline Kecamatan & \multicolumn{4}{c}{ Proporsi Sektor Rumah tangga (\%) } \\
\cline { 2 - 5 } Kabupaten & \multicolumn{1}{c}{$\mathbf{2 0 0 8}$} & \multicolumn{1}{c}{2009} & 2012 & \multicolumn{1}{c}{$\mathbf{2 0 1 5}$} \\
\hline Kab Sleman & 100 & 100 & 100 & 100 \\
Berbah & 3,4 & 3,5 & 4,0 & 4,4 \\
Cangkringan & 1,4 & 1,3 & 1,1 & 1,0 \\
Depok & 29,2 & 28,8 & 27,5 & 26,0 \\
Gamping & 8,8 & 9,1 & 9,8 & 10,5 \\
Godean & 5,0 & 5,0 & 5,1 & 5,1 \\
Kalasan & 5,7 & 5,6 & 5,5 & 5,4 \\
Minggir & 1,6 & 1,5 & 1,3 & 1,1 \\
Mlati & 9,7 & 10,0 & 11,0 & 11,9 \\
Moyudan & 1,9 & 1,8 & 1,4 & 1,1 \\
Ngaglik & 11,0 & 11,1 & 11,3 & 11,5 \\
Ngemplak & 4,5 & 4,5 & 4,4 & 4,3 \\
Pakem & 2,3 & 2,2 & 2,2 & 2,1 \\
Prambanan & 2,5 & 2,4 & 2,0 & 1,8 \\
Seyegan & 2,3 & 2,2 & 1,8 & 1,5 \\
Sleman & 6,2 & 6,4 & 6,9 & 7,3 \\
Tempel & 2,7 & 2,8 & 3,3 & 3,9 \\
Turi & 2,0 & 1,9 & 1,5 & 1,2 \\
\hline
\end{tabular}

Table 3. Proportion of electrical energy consumption by sector business district in Sleman district.

\begin{tabular}{lrrrr}
\hline Kecamatan & \multicolumn{4}{c}{ Proporsi Sektor Bisnis (\%) } \\
\cline { 2 - 5 } Kabupaten & \multicolumn{1}{c}{2008} & \multicolumn{1}{c}{2009} & 2012 & \multicolumn{1}{c}{2015} \\
\hline Kab Sleman & 100 & 100 & 100 & 100 \\
Berbah & 1,2 & 1,5 & 3,3 & 6,6 \\
Cangkringan & 0,7 & 0,7 & 0,6 & 0,5 \\
Depok & 56,7 & 54,9 & 48,5 & 40,7 \\
Gamping & 4,2 & 4,1 & 3,7 & 3,1 \\
Godean & 1,9 & 2,2 & 3,0 & 4,1 \\
Kalasan & 3,5 & 3,2 & 2,5 & 1,8 \\
Minggir & 0,4 & 0,4 & 0,6 & 0,8 \\
Mlati & 9,8 & 10,4 & 12,2 & 13,6 \\
Moyudan & 0,4 & 0,5 & 0,6 & 0,8 \\
Ngaglik & 10,5 & 10,2 & 9,1 & 7,7 \\
Ngemplak & 1,9 & 2,0 & 2,1 & 2,1 \\
Pakem & 2,4 & 2,7 & 3,9 & 5,2 \\
Prambanan & 0,9 & 1,0 & 1,2 & 1,4 \\
Seyegan & 0,3 & 0,4 & 0,6 & 0,9 \\
Sleman & 4,3 & 4,8 & 6,4 & 8,0 \\
Tempel & 0,6 & 0,7 & 1,0 & 1,4 \\
Turi & 0,3 & 0,4 & 0,7 & 1,2 \\
\hline
\end{tabular}

Percentage obtained in the districts Mlati electricity consumption in 2012 to $11.0 \%$ of the household sector and the business sector $12.2 \%$. 
The second discussion on the comparison of the percentage increase in consumption of electrical energy between the business sector to the household sector in 2013 and 2020. Fig. 2 shows the diagram of the business sector demand for electricity consumption. From Fig. 2 it can be seen that there are differences in electricity consumption for the business sectors ranging from 2013 to 2020. These differences indicate an increase in electricity consumption in the following years. Significant rise in electricity consumption visible starting from the year 2018 to 2020 .

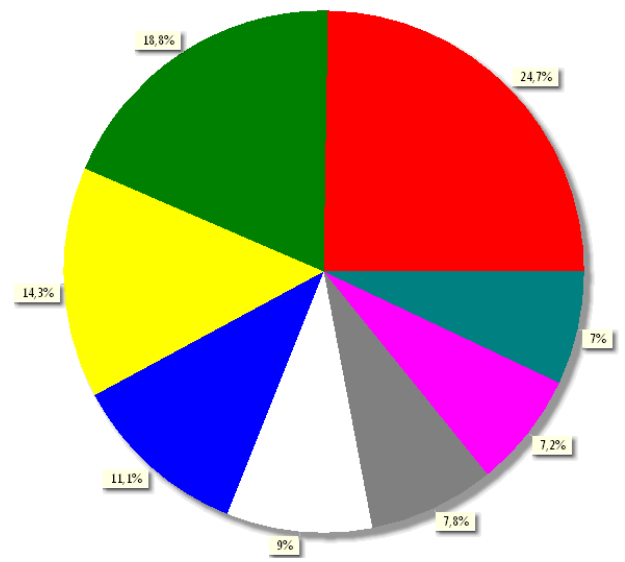

Fig. 2 Percentage of electricity consumption for the business sector in the District Mlati year 2013-2020.

For the actual value in each year can be seen in Table 4. By 2018, electricity consumption amounted to 24.9 GWh business sector with a growth rate of $28.4 \%$. This growth is quite high compared to growth in previous years. Highest electricity consumption growth in 2020 is $32.1 \%$ with a power consumption of 43.2 GWh.

Table 4. Results of the projected electricity consumption for the business sector in the District Mlati year 2013-2020.

\begin{tabular}{|c|c|c|}
\hline No. & Year & Electricity consumption (GWh) \\
\hline 1 & 2013 & 12.2 \\
\hline 2 & 2014 & 12.5 \\
\hline 3 & 2015 & 13.6 \\
\hline 4 & 2016 & 15.8 \\
\hline 5 & 2017 & 19.4 \\
\hline 6 & 2018 & 24.9 \\
\hline 7 & 2019 & 32.7 \\
\hline 8 & 2020 & 43.2 \\
\hline & Total & 174.4 \\
\hline
\end{tabular}


Fig. 3 shows the diagram of the demand of electricity consumption household sector. From Fig. 3 it can be seen that by the year 2013 to 2015 the percentage of its electricity consumption is not much different from the rate of growth is fairly evenly. Something similar happened in 2016 when up to 2017 . While it started in 2018 to 2020 the increase seen significant electricity consumption. Percentage shows in 2018 and 2020 respectively electricity consumption by $14 \% ; 17.5 \%$ and $22.3 \%$. The growth rate from 2018 to 2020 is also quite significant compared to the initial conditions in 2013 and 2015.

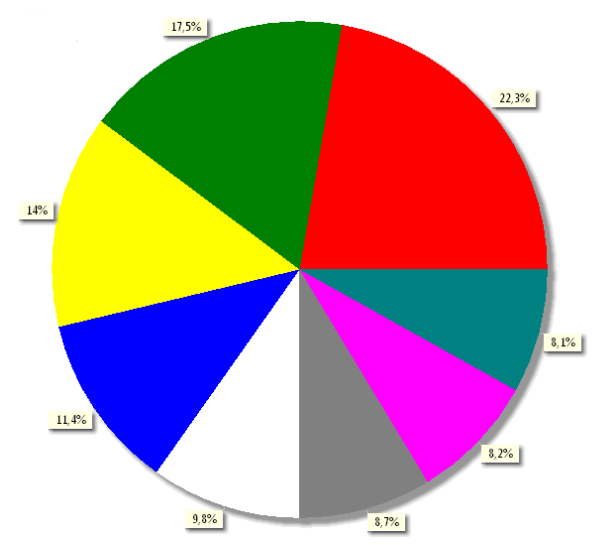

Fig. 3. Percentage of electricity consumption for the household sector in the District Mlati 2013-2020.

For the actual value of electricity consumption in the household sector can be seen in Table 5. Consumption of electricity is very striking look in 2020 is equal to $30.3 \mathrm{GWh}$. High consumption is due to the District Mlati is one of the residential center for students particularly those studying at the University of Gadjah Mada. Therefore, an increase in the number of immigrant students will bring the number of homes or boarding house for rent. It can cause a rise in power consumption.

Table 5. Results of the projected electricity consumption for the household sector in the District Mlati year 2013-2020.

\begin{tabular}{ccc}
\hline No. & Year & Electricity consumption $(\mathrm{GWh})$ \\
\hline 1 & 2013 & 11,0 \\
2 & 2014 & 11.2 \\
3 & 2015 & 11.9 \\
4 & 2016 & 13.3 \\
5 & 2017 & 15.6 \\
6 & 2018 & 19.0 \\
7 & 2019 & 23.8 \\
8 & 2020 & 30.3 \\
& & 136.1
\end{tabular}


If the electricity consumption for the business sector and households are compared, the results of the comparison between the two is not too flashy. The difference between the two ranges from $1 \%$ to $2 \%$. As stated previously, an increase in the number of immigrant students will be able to also increase food business that is ready to sell in about a boarding student. Not only that, other businesses such as supermarkets will also increase the production of their goods given the increasing number of immigrant students who live in District Mlati.

\section{Factors Influencing the Consumption of Electricity}

Activity level of energy in the household sector in 2013 amounted to $8.1 \%$ and in 2020 by $22.3 \%$. Level of activity here represents an increase of energy consumption of electrical energy Mlati districts . It can be seen from the graph of the household sector has always experienced an increase consumption of electrical energy each year and the percentage amount of Ascension has always exceeded the previous years. The number of homes located in the district Mlati with growth of $11.1 \%$ is one of the factors the increase in electrical energy consumption. Also in the districts Mlati own nearly $40 \%$ of homes used as a boarding house for business districts, strategic Mlati the GMU campus. Indirectly it adds to the total number of occupants of the house which in itself adds to the electrical energy consumption.

Then, the activity level of electrical energy on the business sector in 2013 to 2014 amounted to $7 \quad \%$ which goes up significantly in the year 2020 is projected terakahir is equal to $24.7 \%$. Sector Mlati own business in the districts are divided into various kinds, ranging from home eating, minimarket ( Indomaret, Alafamart, CK ), laundry, etc. The number of business sectors in the district Mlati influenced by population growth of $12.5 \%$. The population growth is affected because of the location which is a sub-district Mlati majority GMU student boarding area so many people who saw the business opportunity of the condition. It certainly adds to the number of the business sector in each year .

\section{Conclusion}

LEAP (Long-range Energy Alternative Planning system) helps the planning of energy demand in the future by taking into account population growth, income, and projected energy demand. In the business sector, growth in electricity consumption is highest, ie $32.1 \%$ in 2020 to $43.2 \mathrm{GWh}$ of electricity consumption. In the household sector, growth in electricity consumption is highest, ie $22.3 \%$ in 2020 to $30.3 \mathrm{GWh}$ of electricity consumption. This shows that the demand for electrical energy in the district Mlati from year to year increase. One of the factors that influence the demand for electricity is increasing activity levels and energy consumptive culture.

\section{References}

[1] Pemerintah Kabupaten Sleman. 2013. Evaluasi Hasil Pelaksanaan RKPD dan Capaian Kinerja Penyelenggaraan Pemerintahan Kabupaten Sleman.

[2] Suhono. 2010. Kajian Perencanaan Permintaan Dan Penyediaan Energi Listrik di Wilayah Kabupaten Sleman Menggunakan Perangkat Lunak LEAP. 